\title{
Psikolojik Danışman Adaylarının Süpervizyon Deneyimlerine İlişkin Değerlendirmeleri: Bir Karma Yöntem Çalışması
}

\author{
Uzm. Psk. Dan. Oğuz MERCAN* \\ Milli Eğitim Bakanlı̆̆ı, Eskişehir / Türkiye \\ oguzmercan26@gmail.com, ORCID: 0000-0002-3050-2912 \\ Dr. Asiye DURSUN \\ Millı̂ Eğitim Bakanlı̆̆ı, Eskișehir, Türkiye \\ asiyedursun26@gmail.com, ORCID: 0000-0002-4033-0034
}

\section{$\ddot{O} z$}

Bu çalışma, psikolojik danışman adaylarının süpervizyon süreci deneyimlerinin nitel ve nicel yöntemlerle incelenmesini amaçlamaktadır. Araştırmanın katılımıılarını bir üniversitenin psikolojik danışmanlık ve rehberlik lisans programına devam eden, bireyle psikolojik danışma uygulaması dersini tamamlamış psikolojik danışman adayları oluşturmaktadır. Araştırmanın nitel kısmında, yaşları 21 ile 25 arasında değişen 29'u erkek, 39'u kadın toplam 68 katılımcı yer almıştır. Araştırmanın nicel kısmında ise yaşları 21 ile 24 arasında değişen 19'u erkek 33'ü kadın toplam 52 katılımcı yer almıştır. Çalışmada veri toplama aracı olarak araştırmacılar tarafından hazırlanan kişisel bilgi formu, metafor çalışma formu ve Süpervizyonda Değerlendirme Süreci Envanteri kullanılmıştır. Araştırma sonucunda elde edilen nitel bulgulara göre süpervizyon sürecine ilişkin metaforların süpervizör-aday danışman ilişkisi, rehberlik etme, içgörü kazanma-dönüşüm ve değerlendirme şeklinde dört kategori altında toplandığ 
görülmüştür. Araştırmada elde edilen nicel bulgular, çevrim içi süpervizyon sürecinin yüz yüze süpervizyon sürecine göre anlamlı düzeyde daha etkili olduğunu göstermiştir. Elde edilen bulgular, alanyazın ışığında tartışılmıştır.

Anahtar Kelimeler: Psikolojik danışman eğitimi; Çevrim içi süpervizyon; Yüz yüze süpervizyon; Metafor.

\title{
The Views of Candidate Counselors Regarding Their Supervision Experience: A Mixed-Method Study
}

\begin{abstract}
This study aims to examine the supervision process experiences of psychological counselor candidates with qualitative and quantitative methods. The participants of the study are psychological counselor candidates who are attending a psychological counseling and guidance undergraduate program at a university and who have completed the course of individual counseling practicum. In the qualitative part of the study, a total of 68 participants, 29 male and 39 female, aged between 21 and 25 were included. In the quantitative part of the research, a total of 52 participants, 19 male and 33 female, aged between 21 and 24, took place. In the study, personal information form, metaphor work form and inventory of evaluation process in supervision were used as data collection tools. According to the qualitative findings obtained as a result of the research, it was seen that the metaphors related to the supervision process were grouped under four categories as supervisor-candidate consultant relationship, guiding, gaining insight-transformation and evaluation. The quantitative findings obtained in the study showed that the online supervision process is significantly more effective than the face-to-face supervision process. The findings obtained were discussed in the light of the literature.
\end{abstract}

Keywords: Psychological counselor training; Online supervision; Faceto-face supervision; Metaphor.

\section{Extended Summary}

\section{Purpose}

In the context of psychological counseling, which is one of the psychological assistance professions, one of the most important stages of the education taken is the practice of counseling with individuals and groups. Candidates who are preparing for the profession benefit from supervision processes while taking these courses. Supervision is defined as a relational intervention 
process that is based on evaluation and includes a hierarchical structure, offered by those with more experience in the profession to increase professional functionality and gain perspective to those with less experience (Bernard and Goodyear, 2009). The importance of applied courses, which include the use of professional skills and conducted under supervision, stands out for prospective counselors to acquire a professional identity (Siviş, Çetinkaya and Kara1rmak, 2012). For this reason, supervision-based counseling practices carried out at undergraduate, graduate and doctoral levels require great care.

The effect of the supervision process on professional development and how it is perceived by the people under supervision can be discovered by consulting the opinions of prospective counselors. Addressing the experiences of the candidate counselors in the process, revealing the efficiency of the process and what their expectations are from the process provide data for determining the effectiveness of the supervision process and what the relevant variables are (Atik, 2017).

There are a lot of researches on this subject in the both domestic and international literature. However, in these researches aimed at evaluating the supervision process, face-to-face supervision process is generally the subject of (Amanvermez, Zeren, Erus and Buyruk-Genç, 2020). Similarly, studies are known to be conducted quantitatively or qualitatively rather than mixed designs. In line with these needs the aim of this study, to investigate the views of psychological counselor candidates about the supervision process they have experienced within the scope of the individual counseling course through metaphors and to compare the online and face-to-face supervision processes.

\section{Method}

The mixed research method was used in this study. The mixed research method is expressed as the use of qualitative and quantitative approaches and methods of these approaches together in the study to investigate problem situations (Creswell and PlanoClark, 2011).

In the qualitative part of the mixed research, the phenomenology design, one of the qualitative research designs, was used to determine the supervision process experiences of the psychological counselor candidates within the scope of the individual counseling course. In the quantitative part of the study, a descriptive survey model, one of the quantitative research methods, was used. Based on the responses of the participants for the online and face- 
to-face supervision process, an existing situation was tried to be described.

In the quantitative part of the research, there are a total of 52 participants, 19 male and 33 female, aged between 21 and 24. In the qualitative part of the study, a total of 68 participants, 29 male, 39 female, aged between 21 and 25 are included. Data from the research were obtained through a personal information form, supervision assessment process inventory and metaphor work form.

\section{Results}

Participants in the research developed a total of 68 metaphors, 34 about the face-to-face supervision process and 34 about the online supervision process. The metaphors developed by the psychological counselor candidates are primarily divided into two categories as face-to-face and online processes. Some metaphors are under more than one category as of the meaning they are loaded. Categories related to metaphors; "Supervisor-candidate consultant relationship", "guiding", "gaining insight-transformation", "evaluation".

In the quantitative part of the study, a significant difference was found between the participants who experienced online supervision and the supervision process evaluations of the participants who experienced face-to-face supervision. Based on this finding, it was found that the participants who experience online supervision have more effective supervision experiences than those who experience face-to-face supervision. In addition, it was found that the participants who experienced online supervision experienced more effective feedback in supervision than those who experienced face-to-face supervision.

\section{Discussion}

The metaphors that psychological counselor candidates have formed about face-to-face and online supervision are grouped under four categories: supervisor-psychological counselor candidate relationship, guidance in the supervision process, insight, and evaluation in the supervision process.In this research, it was observed that the metaphors obtained from the participants were similar to the studies conducted on the supervision process in counseling (Aladağ, 2014; Büyükgöze-Kavas, 2011; Erkan-Atik, Arıcı and Ergene, 2014; Erbaş, Koç and Esen, 2020).

In the literature, there are also research findings showing that there is 
no significant difference in effectiveness between the online supervision process and the face-to-face supervision process (Barak and Hen, 2008; Bender and Dykeman, 2016; Cook and Doyle, 2002). It is stated that the competence of supervisors and their ability to use technological tools in the online supervision process affect the efficiency of the online supervision process (Baltrinic, O'Hara and Jencius, 2016; McMahon and Simons 2004). In this sense, it can be stated that the competence of supervisors and their ability to use technological tools increase the efficiency of the online process, unlike the relevant research findings.

\section{Conclusion}

In this study, it was found that the metaphors that psychological counselor candidates have formed about face-to-face and online supervision are grouped under four categories: supervisor-psychological counselor candidate relationship, guidance in the supervision process, insight and evaluation in the supervision process. Besides, it was found that the participants who experience online supervision have more effective supervision experiences than those who experience face-to-face supervision. In addition, it was found that the participants who experienced online supervision experienced more effective feedback in supervision than those who experienced face-to-face supervision.

This study is limited to quantitative and qualitative findings and the characteristics measured by the supervision process assessment inventory and the metaphor work form of the supervision experiences of prospective counselors. Programs can be developed and experimentally tested to help prospective counselors improve the supervision process efficiently. Besides, it is considered important and valuable to carry out different studies to compare online, face-to-face and, hybrid supervision processes.

\section{Giriş}

Psikolojik yardım mesleklerinden olan psikolojik danışmanlık alanında, alınan eğitimin en önemli merhalelerinden biri bireyle ve grupla psikolojik danışma uygulama dersleridir. Mesleğe hazırlanan adaylar bu dersleri alırken süpervizyon süreçlerinden faydalanmaktadır. Süpervizyon; meslekte deneyimi fazla olanların daha az deneyimli olanlara meslekî işlevselliği arttırma ve bakış açısı kazandırma amacıyla sunduğu, değerlendirmeye dayalı olan ve hiyerarşik bir yapı içeren ilişkisel bir müdahale süreci olarak tanım- 
lanmaktadır (Bernard ve Goodyear, 2009). Süpervizyon ilişkisi; başlangıç, olgunluk ve sonlandırma aşamalarından oluşmaktadır (Holloway, 1995). Psikolojik Danışma ve İlgili Programların Akreditasyonu Kurulu [CACREP] (2016) standartlarına göre süpervizyon, aday psikolojik danışmanların aldıkları uygulama ve kurum deneyimi derslerinin en önemli parçasını oluşturmaktadır. Çünkü psikolojik danışma alanında aday psikolojik danışmanların meslekî kimlik edinmelerinin, meslekî becerilerin süpervizyon altında yürütülen uygulamalı derslerle kazandırılabileceği düşünülmektedir (Siviş-Çetinkaya ve Karaırmak, 2012). Benzer şekilde aday danışmanların okul psikolojik danışmanlığ1 görevlerini yetkin biçimde gerçekleştirmesi için süpervizyonun önemi ifade edilmektedir (Özyürek, 2009). Bu nedenle, lisans ve lisansüstü düzeydeki programlarda süpervizyon altında yürütülecek psikolojik danışma uygulamaları büyük özen gerektirmektedir.

Süpervizyon sürecinin, gelişim düzeyine etkisi ve süpervizyon alan kişiler tarafından nasıl algılandığının bilinmesi için aday psikolojik danışmanların görüşlerine başvurulmasına ihtiyaç duyulmaktadır. Aday psikolojik danışmanların süreçteki yaşantılarının ele alınması, sürecin verimliliği ve süreçten beklentilerinin neler olduğunun ortaya konması, süpervizyon sürecinin etkililiğini ve ilgili değişkenlerin ne olduğunu tespit etmeye dönük bir veri sağlamaktadır (Atik, 2017). Alanyazında psikolojik danışman eğitimindeki süpervizyon sürecine yönelik çalışmalar son yıllarda hem yurt içi hem de yurt dış1 araştırmalarda sıklıkla konu edilmektedir (Aladağ ve Bektaş, 2009; Amanvermez, Zeren, Erus ve Buyruk-Genç, 2020; Atik, Çelik, Güç ve Tutal, 2016; Bernard ve Goodyear, 2009; Erbaş, Koç ve Esen, 2020; Ery1lmaz ve Mutlu, 2018; İlhan, Sarıkaya ve Yöntem, 2018; Kalkan ve Can, 2019; McKinley, 2019; Meydan, 2015; Meydan ve Koçyiğit-Özyiğit, 2016; Vannucci, Whiteside, Saigal, Nichols ve Hileman, 2017). Örneğin psikolojik danışman adaylarının gelişimsel süpervizyon modeline yönelik görüşlerinin incelendiği bir araştırmada, süpervizyon oturumlarının tüm aşamalarında hem meslekî hem bireysel gelişim düzeylerine çeşitli yönlerden katkı sağladığg sonucuna ulaşılmıştır (Eryılmaz ve Mutlu, 2018). Lisansüstü öğrenime devam eden 34 psikolojik danışman adayının, bireysel ve grupla psikolojik danışma derslerinde aldıkları süpervizyon hakkındaki görüşlerini belirlemek amacı ile gerçekleştirilen araştırma sonucunda adaylar süpervizörlerini destekleyici, motive edici, samimi ve objektif dönüt veren kişiler olarak algıladıklarını ve olumlu iletişimin süpervizyon sürecine olumlu biçimde yansıdığını, bunların süreci kolaylaştıran faktörler olduğu ifade etmiştir (Büyükgöze-Kavas, 2011). 
Bununla birlikte olumlu ve destekleyici süpervizyon ilişkisinin tüm eğitim düzeylerinde önemli olduğu fakat lisans düzeyinde süpervizyon ihtiyacının daha da arttığı belirtilmektedir (Aladağ, 2014). Bu açıklamalardan süpervizyon sürecinde süpervizör ve aday psikolojik danışman ilişkisinin oldukça önemli olduğu sonucuna ulaşılabilir. Ayrıca süpervizyon ilişkisini etkileyen değişkenler incelendiğinde; süpervizyon alan kişiye ilişkin değişkenler, süpervizöre ilişkin değişkenler (Bernard ve Goodyear, 2009) ve bu iki değişkenin yanında üçlü ilişkideki değişkenlerin (Bradley ve Ladany, 2001) ele alındığı görülmektedir. Benzer şekilde süpervizyon ilişkisinin sadece süpervizor ve aday psikolojik danışman arasındaki ilişki olarak algılanmaması gerektiği, danışanın da süpervizyon ilişkisine etkileri olduğu ve aday psikolojik danışman tarafından süpervizyon ortamına bu etkinin taşındığı düşünülmektedir (Meydan ve Koçyiğit-Özyiğit, 2016). Bununla birlikte aday psikolojik danışmanların ve süpervizörlerin; süpervizyon ilişkisine dair görüşleri kolaylaştırıcı faktörler, zorlaştırıcı faktörler ve etkiler olmak üzere üç tema altında toplandığı görülmektedir (Meydan, 2019). Süpervizyon sürecinde süpervizörlerin ve aday psikolojik danışmanların görüşlerinin süreci anlamlandırmak için oldukça önemli olduğu söylenebilir. Bununla birlikte psikolojik danışman adaylarının sürece ne anlam yüklediklerini anlamanın da önemli olacağı düşünülmektedir. Anlamın dil aracılığıyla var olmasına yardımcı olan yapılardan biri de metaforlardir.

Metaforlar, insanların yaşantılarını ve iç dünyalarını iyi bir şekilde ifade edebilmek için kullandığı araçlar olarak görülmektedir (Levitt, Korman ve Angus, 2000). Metaforlar sayesinde bireyler savunmaya geçmeden ve benlik algisına zarar vermeden problem ve durum hakkında kendilerini daha kolay şekilde ifade edebilmektedir (Carmichael, 2000). Bu anlamda eğitim araştırmalarında metaforlara yönelik çalışmalara sıklıkla rastlanılmaktadır. Matematik (Kaya, 2017; Uygun, Gökkurt ve Neslihan, 2016), yaratıcılık ve drama (Pekdoğan ve Kanak, 2015), müzik (Babacan, 2014) ve öğrenme (Özabacı ve Başak, 2013) gibi konularda metafor çalışmalarının yürütüldüğü bilinmektedir.

Metaforlara yönelik yapılan çalışmalar, psikolojik danışmanlık ve rehberlik alanında da yer bulmaktadır. Bu çalışmalarda psikolojik danışman adaylarının "psikolojik danışma" kavramına ilişkin metaforik algıları (Özpolat, 2014), lise öğrencilerinin rehberlik hizmetlerine ilişkin metaforik algıları (Karataş ve Sönmez, 2019), "psikolojik danışman” kavramına ilişkin metafo- 
rik algılar (Altun ve Camadan, 2013) ve okul psikolojik danışmanlarının mesleklerine ilişkin metaforik algıları (Yıldız ve Türk, 2018) konu edilmiştir. Bu çalışmalarla birlikte psikolojik danışman adaylarının deneyimledikleri süpervizyon sürecine ilişkin metaforik algılarını konu edinen bir çalışmaya rastlanılmamıştır. Bu konuya benzer nitelikte yapılan bir durum çalışmasında elde edilen bulgularda; psikolojik danışman ve süpervizör ilişkisinin niteliği, süpervizyon sürecine ait niteliği, süpervizyon sürecinin psikolojik danışma sürecine olan katkısı ve süpervizyon sürecinin meslekî-kişisel gelişime olan katkıs1 olmak üzere dört ana temanın ortaya çıktığı ifade edilmiştir (Erbaş, Koç ve Esen, 2020).

Metaforların anlam dünyasına ulaşmada ve direnç olmadan duruma dair duygu ve düşünceleri ifade etmede kolaylaştırıcı etkisi düşünüldüğünde psikolojik danışman adaylarının süpervizyon sürecine yükledikleri anlamlara metaforlar aracılığ ile ulaşılabileceği düşünülmektedir. Bu açıklamalar doğrultusunda bu araştırmada bireyle psikolojik danışma uygulaması dersi kapsamında süpervizyon alan aday psikolojik danışmanların deneyimledikleri süpervizyon sürecine yönelik algıları metaforlar yoluyla incelenmiştir. Öte yandan çalışmanın nicel kısmını oluşturan çevrim içi ve yüz yüze deneyimlenen süpervizyon süreçlerinin karşılaştırılması da bu çalışmanın amaçlarından biridir. Alanyazında yer alan süpervizyon sürecinin değerlendirilmesine yönelik çalışmalarda genellikle yüz yüze süpervizyon süreci konu edilmektedir (Amanvermez, Zeren, Erus ve Buyruk-Genç, 2020). Gelişen teknolojik imkânlar sayesinde psikolojik danışma hizmeti çevrim içi olarak verileceği gibi süpervizyon süreci de benzer şekilde çevrim içi olarak da yürütülebilmektedir (Rousmaniere, 2014). Süpervizyon sürecinin yüz yüze gerçekleştirilen formattan farklılaşmaya başlayarak e-süpervizyon olarak ifade edilen yapıya kavuşması kaçınılmaz bir durum olarak ifade edilmektedir (Bacigalupe, 2010). Bu anlamda süpervizyon süreçlerinde video konferans, video kaydı, eposta ve yazılı dökümlerin incelenmesi gibi farklı yöntemlerden de yararlanılabilmektedir (Kanz, 2001). Özellikle salgın hastalık, doğal afet ve benzeri kısıtlayıcı durumların hâkim olduğu zamanlarda, psikolojik danışman eğitiminde çevrim içi süpervizyon sürecinin daha fazla önem kazandığı düşünülmektedir. Alanyazında süpervizyon sürecinin etkililiğini konu alan çalışmalarda, bahsedilen süreçlerin yaşanmadığg görülmektedir. Çevrim içi psikolojik danışma ve süpervizyon sürecinin zorunlu olarak yürütülmesi gereken süreçlerde bu hizmetlerin etkililiğinin anlaşılmasının önemli olduğu düşünülmek- 
tedir. Bununla birlikte yüz yüze süpervizyon ve çevrim içi süpervizyon süreçlerini ele alıp karşılaştıran araştırmaların sınırlı sayıda olduğu görülmektedir. $\mathrm{Bu}$ araştırmanın, hem aday psikolojik danışmanların yüz yüze ve çevrim içi süpervizyon süreçlerine yükledikleri anlamlara hem de süpervizyon sürecini değerlendirmeleri bakımından süpervizyon yaşantılarının daha iyi anlaşılmasına 1şık tutacağı düşünülmektedir.

$\mathrm{Bu}$ bağlamda bu araştırmanın amacı, psikolojik danışman adaylarının bireyle psikolojik danışma uygulaması dersi kapsamında deneyimledikleri süpervizyon süreci hakkındaki görüşlerini metaforlar aracılığıyla incelemek ve çevrim içi-yüz yüze deneyimlenen süpervizyon süreçlerini karşılaştırmaktır. Araştırmanın amacı kapsamında aşağıdaki sorulara cevap aranacaktır:

1. Psikolojik danışman adaylarının süpervizyon süreci ile ilgili sahip oldukları metaforlar nelerdir?

2. Psikolojik danışman adaylarının oluşturdukları metaforlar hangi kavramsal kategoriler altında toplanmıştır?

3. Yüz yüze ve çevrim içi süpervizyon deneyimine sahip psikolojik danışman adaylarının, süpervizyon süreci değerlendirme envanterine verdikleri puanlar arasında anlamlı bir farklılık var mıdır?

\section{Araştırma Modeli}

\section{Yöntem}

$\mathrm{Bu}$ araştırmada karma araştırma yöntemi kullanılmıştır. Karma araştırma yöntemi, problem durumlarını keşfetmek amacıyla çalışma içinde nitel ve nicel yaklaşımlar ile bu yaklaşımlara ait yöntemlerin bir arada kullanılması olarak ifade edilmektedir (Creswell ve PlanoClark, 2011).

Karma araştırmanın nitel kısmında, bireyle psikolojik danışma uygulaması dersi kapsamında psikolojik danışman adaylarının süpervizyon süreci deneyimlerinin metaforlar yoluyla belirlenmesi amacı doğrultusunda nitel araştırma desenlerinden olgu bilim deseni kullanılmıştır. Olgu bilim deseninde, hayatî ve eğitsel deneyimlerin derinlemesine şekilde ayrıntılı olarak bütüncül bir yapıda incelenmesi amaçlanmaktadır (Yıldırım ve Şimşek, 2013). Öte yandan nitel araştırma desenindeki çalışmalarda veri toplama amacıyla metaforlardan yararlanılması, gizil kalmış yapıların açıklanabilmesi ve karmaşık olarak nitelendirilen fikirlerin somutlaştırılması gibi faydaları içerdiğinden betimleyici bir özelliği de simgelemektedir (Sidekli, Pekdemir ve Yorulmaz, 2021). 
Araştırmanın nicel kısmında ise nicel araştırma yöntemlerinden betimsel tarama modeli kullanılmıştır. Çevrim içi ve yüz yüze süpervizyon sürecine yönelik katılımcıların ölçme aracına verdikleri yanıtlardan hareketle var olan bir durum betimlenmeye çalışılmıştır.

\section{Çalışma Grubu/Katılımcılar}

$\mathrm{Bu}$ çalışmada örnekleme yöntemi olarak amaçlı örnekleme yöntemi kullanılmıştır. Amaçlı örnekleme yöntemi, bilgi açısından yeterli düzeydeki bireylere ulaşılmasını içermektedir (Patton, 2002). Çalışma grubunun belirlenmesinde ise amaçlı örnekleme yöntemlerinden ölçüt örnekleme yöntemi kullanılmıştır. Çalışma grubuna alınan bireylerin ölçütleri ise:

- Araştırmaya gönüllü olarak katıldıklarını beyan etmeleri

- Araştırmanın gerçekleştirildiği süre içerisinde bir üniversitenin psikolojik danışmanlık ve rehberlik lisans programında eğitim görüyor olmalar1

- Araştırmanın gerçekleştirildiği süre içerisinde bireyle psikolojik danışma uygulaması dersi kapsamında süpervizyon sürecini deneyimlemeleri olarak belirlenmiştir.

Araştırmanın katılımcılarını, bir yükseköğretim kurumunun psikolojik danışmanlık ve rehberlik lisans programında eğitim gören ve bireyle psikolojik danışma uygulaması dersini başarıyla tamamlamış psikolojik danışman adayları oluşturmaktadır.

Araştırmanın nicel kısmında, yaşları 21 ile 24 arasında değişen 19'u erkek 33'ü kadın toplam 52 katılımcı yer almaktadır. Araștırmanın nitel kısmında ise yaşları 21 ile 25 arasında değişen 29'u erkek 39'u kadın toplam 68 katılıme yer almaktadır.

\section{Veri Toplama Araçları}

Araştırmadan veriler kişisel bilgi formu, süpervizyon değerlendirme süreci envanteri ve metafor çalışma formu ile elde edilmiştir.

\section{Kişisel Bilgi Formu (KBF)}

Araştırmacılar tarafindan hazırlanan kişisel bilgi formunda, katılımcıların yaş ve cinsiyet gibi bazı demografik özelliklerine yönelik sorular yer almaktadır.

\section{Süpervizyonda Değerlendirme Süreci Envanteri (SDSE)}

Süpervizyonda Değerlendirme Süreci Envanteri, Lehrman-Waterman 
ve Ladany (2001) tarafindan geliştirilmiş; Türkçeye uyarlanması Erkan Atik ve Yıldırım (2017) tarafından gerçekleştirilmiştir.

SDSE'de toplam 14 madde yer almakta, amaç belirleme ve geri bildirim olmak üzere iki alt boyut bulunmaktadır. Amaç belirleme boyutu 6 maddeden (örneğin "Süpervizörümle birlikte benim için anlaşılması kolay amaçlar oluşturduk."), geri bildirim boyutu ise 8 maddeden (örneğin "Süpervizörüm geri bildirimlerinde olumlu ve olumsuz ifadeleri dengeli kullandı.") oluşmaktadır. Ölçekte bir madde ters puanlanmaktadır. Ölçme aracındaki maddeler 7'li likert tipi bir derecelendirme (1=Hiç katılmıyorum, 7=Tamamen katılıyorum) üzerinden cevaplanmaktadır. Ölçme aracının uyarlanması sürecinde elde edilen bulgulara göre, ölçme aracının tümüne ilişkin güvenirlik katsayısı .92, amaç belirleme boyutu için .85 ve geri bildirim boyutu için .89 olarak bulunmuştur. Ölçme aracının yapı geçerliliğini test etmek için kullanılan analizlerde ise ölçme aracınınn iyi uyum indekslerine sahip olduğu belirtilmiştir [ $\chi 2(4$, 274) $=7.50, p=.11, \mathrm{GFI}=.99, \mathrm{CFI}=.99, \mathrm{NNFI}=.98]$ (Erkan-Atik ve Y1ldırım, 2017). Bu çalışmada ise ölçeğin tamamına ilişkin hesaplanan güvenirlik katsayıs1 .88 , amaç belirleme boyutu için .86 , geri bildirim boyutu içinse .80 olarak elde edilmiştir.

\section{Metafor Çalışma Formu}

Çalışmanın nitel kısmına yönelik araştırmacılar tarafından oluşturulan metafor çalışma formunda, yarı yapılandırılmış bir form oluşturularak katılımcıların boş olan yerleri doldurmaları istenmiştir (örneğin 'Süpervizyon benim için ....... gibidir/benzer; çünkü ......'). Katılımcıların belirtilen form üzerinde tamamladıkları bu cümleler, çalışmanın nitel kısımdaki veri kaynağını oluşturmuştur.

\section{Veri Toplanması ve Analizi}

Araştırmada yer alan katılımcılardan elde edilen veriler, 12 aylık süreç içerisinde ve 2 farklı zamanda toplanmıştır. Bu süre içerisindeki verilerin toplanmasındaki ilk aşamada süpervizyon süreci yüz yüze gerçekleştirilmiş, ikinci veri toplama aşamasının süpervizyon süreci ise pandemi nedeniyle çevrim içi olarak gerçekleştirilmiştir. Verilerin toplanmasında yüz yüze ve çevrim içi veri toplama yöntemleri kullanılmıştır. Her bir uygulama yaklaşık 10 dakika sürmüştür.

Araştırmada elde edilen nicel veriler SPSS 22.0 paket programı kullanılarak, nitel veriler ise içerik analizi yöntemi kullanılarak analiz edilmiştir. 
Nicel verilerin öncelikle normal dağılımdan gelip gelmediği incelenmiştir. Bunun için Kolmogorov-Smirnov normallik testi uygulanmış ve elde edilen değerin istatistiksel anlamlılık düzeyinden küçük çıtığı tespit edilmiştir $(p<.05)$. Bunun üzerine, verilerin normal dağılımdan gelip gelmediğinin test edilmesinde kullanılan bir başka yöntem olan basıklık-çarpıklık değerlerinden faydalanılmıştır. Çarpıklık-basıklık değerinin \pm 1.96 arasında olması, verilerin normal dağılımdan geldiğinin bir göstergesi olarak ifade edilmektedir (Tabachnick ve Fidell, 2007). Yapılan analiz sonucunda elde edilen çarpıklık-basıklık değerinin, belirtilen aralıkta olmadığı görülmüştür. Her iki testten de elde edilen sonuçlardan hareketle, verilerin normal dağıllimdan gelmediğine karar verilmiştir. Bu nedenle "Yüz yüze ve çevrim içi süpervizyon deneyimine sahip psikolojik danışman adaylarının, süpervizyon süreci değerlendirme envanterine verdikleri puanlar arasında anlamlı bir farklılık var mıdır?" araştırma sorusunun analizi için parametrik olmayan testlerden Mann Whitney-U tercih edilmiştir.

Araştırmanın nitel kısmında iki araştırmacı birbirinden bağımsız şekilde veri kodlaması yapmıştır. Ardından araştırmacılar tarafından oluşturulan kodlamalar bir araya getirilip gerekli incelemeler yapılarak üzerinde görüş birliğine varılan ve görüş birliğine varılamayan kodlar belirlenmiştir. Uzmanların görüş birliğine vardığı kod sayısının, görüş birliği olan ve olmayan toplam kod sayısına bölünmesiyle elde edilen kodlayıcılar arası güvenirlik oranının \%70'ten düşük olmaması gerektiği bilinmektedir (Miles ve Huberman, 1994). Araştırmada bu güvenirlik formülü ile kodlayıcılar arası güvenirlik oranı $\% 82$ olarak hesaplanmıştır. Nitel bulguların kodlanmasında araştırma bulgularının doğruluğuna yönelik geçerlik ve tekrarlanabilirliğe yönelik güvenirlik ilkeleri gözetilmiştir (Yıldırım ve Şimşek, 2013). Elde edilen temalar araştırmacılar haricinde ilgili alanda çalışan iki uzman tarafından ayrı ayrı incelenmiş ve oluşturulan kategorilere ilişkin görüşleri alınmıştır. Son aşamada nitel verilere ait kategorilere son hâli verilmiştir.

\section{Bulgular}

Araştırmanın bulguları nitel ve nicel bulgular başlıkları altında ele alınmiştır.

\section{Araştırmada Elde Edilen Nitel Bulgular}

$\mathrm{Bu}$ başlık altında, aşağıdaki araştırma sorularına yönelik elde edilen bulgulara yer verilmiştir. 
1. Psikolojik danışman adaylarının süpervizyon süreci ile ilgili sahip oldukları metaforlar nelerdir?

2. Psikolojik danışman adaylarının oluşturdukları metaforlar hangi kavramsal kategoriler altında toplanmıştır?

Araştırmaya katılan katılımcılar yüz yüze gerçekleştirilen süpervizyon sürecine ilişkin 34, çevrim içi gerçekleştirilen süpervizyon sürecine ilişkin 34 olmak üzere toplam 68 metafor geliştirmişlerdir. Psikolojik danışman adaylarının geliştirmiş oldukları metaforlar öncelikle yüz yüze ve çevrim içi süreç olarak iki kategoriye ayrılmıştır. Ardından tüm metaforlar birlikte ele alınmış ve 4 kategoriye ayrılmıştır. Bazı metaforlar yüklendiği anlam itibarıyla birden fazla kategori altında bulunmaktadır. Metaforlara ilişkin kategoriler; "süpervizör-aday danışman ilişkisi", "rehberlik etme", "içgörü kazanma-dönüşüm”, "değerlendirme" şeklindedir.

Tablo 1. Katılımcıların "Yüz Yüze ve Çevrim İçi Süreç" Kategorisine İlişkin Metaforlarının Frekans ve Yüzde Dă̆glımı

\begin{tabular}{|c|c|c|c|c|c|}
\hline Yüz Yüze Metafor & $\mathbf{F}$ & $\%$ & Çevrim İçi Metafor & $\mathbf{F}$ & $\%$ \\
\hline Yolculuk (gemi, tren) & 3 & 8.83 & Yolculuk & 5 & 14.70 \\
\hline Buğulu cam & 1 & 2.94 & Film & 1 & 2.94 \\
\hline Sürpriz yumurta & 1 & 2.94 & Ayçiçeği-güneş ilişkisi & 1 & 2.94 \\
\hline Dil öğrenmek & 1 & 2.94 & Fener (el, deniz) & 3 & 8.83 \\
\hline Ağaç & 3 & 8.83 & Kitap okumak & 2 & 5.89 \\
\hline Uzun bir köprü & 1 & 2.94 & Puzzle & 1 & 2.94 \\
\hline Deniz kabuğu arayışı & 1 & 2.94 & Bumerang & 1 & 2.94 \\
\hline Kaplumbağa & 1 & 2.94 & Jüri & 1 & 2.94 \\
\hline İletişim & 1 & 2.94 & Maraton koşmak & 3 & 8.83 \\
\hline El feneri & 1 & 2.94 & Baygınken atılan tokat & 1 & 2.94 \\
\hline Kilden portre yapmak & 1 & 2.94 & Bina inşa etmek & 1 & 2.94 \\
\hline Ağaç kökü & 2 & 5.89 & Gelişim & 1 & 2.94 \\
\hline Yol-yolcu-gezgin & 4 & 11.77 & Okuma yazma öğrenme & 1 & 2.94 \\
\hline Tünelden aydınlığa çıkış & 1 & 2.94 & Pusula & 1 & 2.94 \\
\hline Kuyudan çıkış & 1 & 2.94 & Gözlük & 1 & 2.94 \\
\hline Mevsim değişimi & 1 & 2.94 & Yön bulma levhası & 1 & 2.94 \\
\hline Ayna & 1 & 2.94 & Kasa kilidi & 1 & 2.94 \\
\hline Tirtıl kelebek dönüşümü & 1 & 2.94 & Yüzme öğrenmek & 1 & 2.94 \\
\hline Tetris oyunu & 1 & 2.94 & Ăgaç & 1 & 2.94 \\
\hline Tiyatro & 1 & 2.94 & Kuyudan çıkış & 1 & 2.94 \\
\hline Kargo takip süreci & 1 & 2.94 & Yol (virajlı, engebeli, 1şıklı) & 3 & 8.83 \\
\hline Özgürlük & 1 & 2.94 & İğne iplik & 1 & 2.94 \\
\hline İyileşen kanser hücresi & 1 & 2.94 & Gölge ile yürüme & 1 & 2.94 \\
\hline Yapboz & 1 & 2.94 & & & \\
\hline Yırtık ve sararmış kâğıt & 1 & 2.94 & & & \\
\hline Domino taşı & 1 & 2.94 & & & \\
\hline Toplam & 34 & 100 & & 34 & 100 \\
\hline
\end{tabular}


Katılımcıların "yüz yüze ve çevrim içi süreç” kategorisine ait geliştirmiş oldukları metaforların frekans ve yüzde dağılımı Tablo 1'de verilmiştir. Tablo 1 incelendiğinde yüz yüze süpervizyon alan psikolojik danışman adaylarının 26 farklı metafor oluşturdukları, çevrim içi süpervizyon alan psikolojik danışman adaylarının ise 23 farklı metafor oluşturdukları görülmektedir. İki kategoride de yolculuk-yol-yolcu metaforlarının (yüz yüze: 7, çevrim içi: 8) diğer metaforlara göre ön plana çıktığı görülmektedir. Ayrıca kuyudan çıkış, fener ve ağaç metaforları iki kategoride de yer almaktadır. Tabloya göre psikolojik danışman adaylarının hem yüz yüze hem de çevrim içi süreçte aldıkları süpervizyon deneyimlerini en çok yolculuk ve yol metaforu ile anlamlandırdıkları görülmektedir. İlgili metaforlar ve metaforlara yüklenen anlamlardan birkaç örnek şu şekildedir:

"Süreci gemi yolculuğuna benzetiyorum. Okyanusun ortasında etrafa baktığımda yön bulmak neredeyse anlamsızdır. Kendimi geminin dümenini yerleştirdim ve limandan dikkatlice uzaklaşarak sürece başladım. Ardından pusula ve haritalarımla (süpervizor süreciyle) yönümü bulmakta çok zorlanmadım çünkü bu süreç bana güven verdi. Hem kendime hem de süpervizör sürecine karşı beslediğim güven ve beklentiler sonucu gemiyi doğru limana götürebilmek için inancım ve çabamla başarabildiğimi düşünüyorum. Bu yolda ögrenmem gereken çok fazla liman ve yol var ancak önemli olan yola umutla çıkabilmek." Yüz yüze süreç

"Benim için süpervizyon süreci virajlı bir yol gibiydi. Çünkü direksiyonda ben vardım ama yolu bilmiyordum. Süpervizörüm bana co-pilotluk yaparak virajlı yolda ilerlememi sağladı." Çevrim içi süreç

"Süreç rotası belli olmayan bir yolculuğa çıkmak gibiydi. Rotayı belirleyen danışan, elime haritayı tutuşturup "hadi yolunu bul” diyen süpervizör, aracı kullanan ise bendim”. Çevrim içi süreç

Katılımcıların oluşturdukları metaforlar içerdikleri anlam bakımından kategorileştirmesi sonucunda dört farklı kategori elde edilmiştir. "Süpervizöraday danışman ilişkisi”, "rehberlik etme”, "dönüşüm/içgörü kazanma” ve “değerlendirme" olarak isimlendirilen kategoriler ve metaforlar sirası ile Tablo 2, Tablo 3, Tablo 4 ve Tablo 5'te sunulmaktadır. Katılımcıların “süpervizör-aday danışman ilişkisi” kategorisine ait geliştirmiş oldukları metaforların frekans ve yüzde dağılımı Tablo 2'de verilmiştir. 
Tablo 2. Katılımcıların "Süpervizör-Aday Danışman İlişkisi” Kategorisine İlişkin Metaforlarının Frekans ve Yüzde Dağılımı

\begin{tabular}{|c|c|c|c|c|c|}
\hline Yüz Yüze Metafor & $\mathbf{F}$ & $\%$ & Çevrim İçi Metafor & $\mathbf{F}$ & $\%$ \\
\hline Yolculuk (gemi, tren) & 2 & 22.23 & Yolculuk & 2 & 16.70 \\
\hline Deniz kabuğu arayışı & 1 & 11.11 & Gözlük & 1 & 8.33 \\
\hline Kuyudan çı1kış & 1 & 11.11 & Ayçiçeği-güneş ilişkisi & 1 & 8.33 \\
\hline İletişim & 1 & 11.11 & Fener (el, deniz) & 1 & 8.33 \\
\hline Tırtıl-kelebek dönüşümü & 1 & 11.11 & Bumerang & 1 & 8.33 \\
\hline Kargo takip süreci & 1 & 11.11 & Maraton koşmak & 1 & 8.33 \\
\hline Ağaç kökü & 1 & 11.11 & Bumerang & 1 & 8.33 \\
\hline \multirow{4}{*}{ Yol-yolcu-gezgin } & 1 & 11.11 & Yüzme öğrenmek & 1 & 8.33 \\
\hline & & & Gölge ile yürüme & 1 & 8.33 \\
\hline & & & Kuyudan çıkış & 1 & 8.33 \\
\hline & & & Yol (virajlı, engebeli, 1şıklı) & 1 & 8.33 \\
\hline Toplam & ? & 100 & & 12 & 100 \\
\hline
\end{tabular}

Tablo 2 incelendiğinde "süpervizör-aday danışman ilişkisi” kategorisinde yüz yüze süpervizyon alan psikolojik danışman adaylarının 9 farklı metafor oluşturdukları, çevrim içi süpervizyon alan psikolojik danışman adaylarının ise 12 farklı metafor oluşturdukları görülmektedir. İki kategoride toplam 21 metafor yer almaktadır. Tabloya göre psikolojik danışman adaylarının hem yüz yüze hem de çevrim içi süreçte aldıkları süpervizyon deneyimlerini en çok yolculuk ve süpervizör ile ilişkilerini yolculuk metaforu ile anlamlandırdıkları görülmektedir. İlgili metaforlar ve metaforlara yüklenen anlamlardan birkaç örnek şu şekildedir:

"Süreci gemi yolculuğuna benzetiyorum. Okyanusun ortasinda etrafa baktığımda yön bulmak neredeyse anlamslzdır. Kendimi geminin dümenini yerleş̧tirdim ve limandan dikkatlice uzaklaşarak sürece başladım. Ardindan pusula ve haritalarımla (süpervizyon süreciyle) yönümü bulmakta çok zorlanmadım çünkü bu süreç bana güven verdi. Hem kendime hem de süpervizör sürecine karşı besledig̈im güven ve beklentiler sonucu gemiyi doğru limana götürebilmek için inancım ve çabamla başarabildiğimi düşünüyorum. Bu yolda öğrenmem gereken çok fazla liman ve yol var ancak önemli olan yola umutla çıkabilmek." Yüz yüze süreç

"Sürecimi deniz knyısında; suların içerinde deniz kabuğu arayışına benzetiyorum. Bu dersi seçerken doğru kiyı olarak sizi seçtiğimi düşünüyorum. Ardindan her geri bildirimde vermiş olduğunuz dönütlerle o kabuğunun içerisindeki sesleri ihtiyaç duyduğumda dinleyebildiğimi düşüyorum. Bu doğrultuda süpervizyon sürecim boyunca etkili bir şekilde ilerlediğimi ve kendimi keşfederek süreci sağllklı bir şekilde sonlandırdiğımı düşünüyorum.” Yüz yüze süreç 
"Gölgeyle birlikte yürümek gibiydi. Bu metafor öncelikli olarak okunduğunda olumsuz algllanabilir fakat tam olarak öyle değil. İlk defa çıktığım bir süreçte yanımda olduğunu bildiğim için güven duyduğum, bununla beraber süreci somut bir şekilde eline almadan bana bıraktı̆̆ için gölgeye benzettiğim bir süreç oldu." Çevrim içi süreç

"Benim için süpervizyon süreci dip bir kuyudan halat yardımıyla kurtulmak gibiydi. Çünkü ilk defa bir danışma süreci yürüttüm. Bu sürece ilk başladığımda kendimi karanlık dip bir kuyuda, çaresiz ve oradan kurtulmak için bekleyen biriydim. Daha sonra biri gelip bana bir halat sarkıtarak o dip ve karanlık kuyudan yavaş yavaş çıkarttı." Çevrim içi süreç

"Dağa tırmanmak gibiydi çünkü zorlu bir yolculuktu iniş ve çıkışlardan oluşuyordu. Bazen zorlandım zorlandığım noktalarda süpervizörüm ile onun desteği ile yola devam ederek motivasyonumu kaybetmedim." Çevrim içi süreç

Katılımcıların "rehberlik etme" kategorisine ait geliştirmiş oldukları metaforların frekans ve yüzde dağılımı Tablo 3'te verilmiştir.

Tablo 3. Katılımcıların "Rehberlik Etme” Kategorisine İlişkin Metaforlarının Frekans ve Yüzde Dağılımı

\begin{tabular}{llllll}
\hline Yüz Yüze Metafor & $\mathbf{F}$ & $\mathbf{\%}$ & Çevrim İçi Metafor & F & \% \\
\hline Yolculuk (gemi, tren) & 2 & 12.50 & Yolculuk & 1 & 5.55 \\
El feneri & 1 & 6.25 & Bina inşa etmek & 1 & 5.55 \\
Sürpriz yumurta & 1 & 6.25 & Ayçiçeği-güneş ilişkisi & 1 & 5.55 \\
Uzun bir köprü & 1 & 6.25 & Fener (el, deniz) & 3 & 16.50 \\
Deniz kabuğu arayışı & 1 & 6.25 & Ağaç & 1 & 5.55 \\
Ağaç & 2 & 12.50 & Puzzle & 1 & 5.55 \\
Yol-yolcu-gezgin & 2 & 12.50 & Bumerang & 1 & 5.55 \\
Tiyatro & 1 & 6.25 & Pusula & 1 & 5.55 \\
Kargo takip süreci & 1 & 6.25 & Gözlük & 1 & 5.55 \\
İyileşen kanser hücresi & 1 & 6.25 & Yön bulma levhası & 1 & 5.55 \\
Yapboz & 1 & 6.25 & Yol (virajlı, engebeli, 1şıklı) & 2 & 11.10 \\
Kuyudan çıkış & 1 & 6.25 & İğne iplik & 1 & 5.55 \\
Tirtıl kelebek dönüşümü & 1 & 6.25 & Gölge ile yürüme & 1 & 5.55 \\
& & & Yüzme öğrenmek & 1 & 5.55 \\
\hline Toplam & $\mathbf{1 6}$ & $\mathbf{1 0 0}$ & & $\mathbf{1 8}$ & $\mathbf{1 0 0}$ \\
\hline
\end{tabular}

Tablo 3 incelendiğinde "rehberlik etme" kategorisinde yüz yüze süpervizyon alan psikolojik danışman adaylarının 16 farklı metafor oluşturdukları, çevrim içi süpervizyon alan psikolojik danışman adaylarının ise 18 farklı metafor oluşturdukları görülmektedir. İki kategoride toplam 34 metafor yer almaktadır. Tabloya göre psikolojik danışman adaylarının süpervizyon sürecindeki "süpervizör-danışman adayı ilişkisi”" kategorisine ait metaforlara benzer 
metaforlar olmakla birlikte farklı metaforlar ile de anlamlandırdıkları görülmektedir. İlgili metaforlar ve metaforlara yüklenen anlamlardan birkaç örnek şu şekildedir:

\begin{abstract}
"Benim için danışma süreci "sürpriz bir yumurta" gibi. Her oturumda danışan size bir bütünü oluşturacak parçalarl veriyor. Onları birleş̧tirmeye yardim eden bir kilavuz (süpervizör, ek kaynaklar) olsa da nasıl ki sürpriz yumurtadan çıkan parçaları birleştirirken el becerisi devreye giriyorsa danışma sürecinde de danışmanin tepkilerindeki gelişmeler, süreci yönetilme becerisi, doğru müdahaleleri seçebilmesi devreye giriyor. Bu açıdan parçaları nasıl birleştirmen gerektiğini süreç içerisinde öğreniyorsun. Süreç sonundaki danışandaki değişimlerde birleştirmedeki başarını gösteriyor. Ĕger doğru bir yöntemle bu parçaları birleştirdiysen danışanın olumlu değişimi seni mutlu eden bir hediye gibi karşında duruyor. Emeklerinin karşıllğını aldlğını görebiliyorsun." Yüz yüze süreç
\end{abstract}

"Gürül gürül akan bir derenin üzerindeki uzun köprüden geçmek gibiydi. Eğer köprüden düssseydim, suya kapılıp giderdim. Muhtemelen bu ilk deneyimimde aldığım darbe de bende kalıcı izler birakirdı. Bunun yerine o uzun köprüden düsmeden, zaman zaman dengemi kaybetsem de yaralanmadan geçebildim. Çünkü yolu çok iyi bilen bir rehberim vard.." Yüz yüze süreç

"Benim için süpervizyon süreci puzzle çz̈zmek gibiydi. Çünkü her oturumdan sonra dăğlan parçaları toplamamı ve ana resmi görmemi sağladl." Çevrim içi süreç

"Benim için süpervizor süreci bir inşaat mühendisinin ilk projesini hayata geçirmesi gibiydi, proğramlarl, çizimleri ögrenmiş ve hayali yaptlar tasarlamış bu mühendis artı sahaya indi ve gerçek bir yapı tasarlama sürecine girdi. Bu süreçte yapacağl doğrular ve yanlışlar insanların yaşamına etki edecekti. Biz bu süreçte temeli ve kolonları sağlam atarak insanlara zarar vermemeyi başardiktan sonra onların hayatlarını güzelleştirmeye çalıştık. Artık sağlam temel atıp, sağlam kolonlar dikebiliyorum. Binam ylkllmayacak ve benden yardım isteyen hastalara zarar vermeyeceğimi biliyorum. Bu temeli ve kolonlart diktikten sonra insanlar için yararlı yapılar yapmak daha kolay olacak." Çevrim içi süreç

Katılımcıların "içgörü kazanma/dönüşüm” kategorisine ait geliştirmiş oldukları metaforların frekans ve yüzde dağılımı Tablo 4'te verilmiştir. Tablo 4 incelendiğinde "içgörü kazanma/dönüşüm” kategorisinde yüz yüze süpervizyon alan psikolojik danışman adaylarının 19 farklı metafor oluşturdukları, çevrim içi süpervizyon alan psikolojik danışman adaylarının ise 10 farklı me- 
tafor oluşturdukları görülmektedir. İki kategoride toplam 29 metafor yer almaktadır.

Tablo 4. Katılımcıların “İçgörü Kazanma/Dönüşüm” Kategorisine İlişkin Metaforlarının Frekans ve Yüzde Dağglımı

\begin{tabular}{llllll}
\hline Yüz Yüze Metafor & F & $\mathbf{\%}$ & Çevrim İçi Metafor & F & $\mathbf{\%}$ \\
\hline Yolculuk & 1 & 5.26 & Yolculuk & 1 & 10 \\
Buğulu cam & 1 & 5.26 & Baygınken atılan tokat & 1 & 10 \\
Kaplumbağa & 1 & 5.26 & Fener & 1 & 10 \\
Dil öğrenmek & 1 & 5.26 & Gelişim & 1 & 10 \\
Ağaç & 1 & 5.26 & Kitap okumak & 2 & 20 \\
Kilden portre yapmak & 1 & 5.26 & Ağaç & 1 & 10 \\
Ağaç kökü & 2 & 10.52 & Kuyudan çııış & 1 & 10 \\
Mevsim değişimi & 1 & 5.26 & Yol (virajlı, engebeli, ş̧ıklı) & 1 & 10 \\
Ayna & 1 & 5.26 & Kasa kilidi & 1 & 10 \\
Tirtıl kelebek dönüşümmü & 1 & 5.26 & & & \\
Tetris oyunu & 1 & 5.26 & & & \\
Tiyatro & 1 & 5.26 & & & \\
Domino taşı & 1 & 5.26 & & & \\
Tünelden aydınlı̆ga çıkış & 1 & 5.26 & & & \\
Özgürlük & 1 & 5.26 & & & \\
İyileşen kanser hücresi & 1 & 5.26 & & & \\
Yapboz & 1 & 5.26 & & $\mathbf{1 0}$ & $\mathbf{1 0 0}$ \\
Yurtık ve sararmış kâğı̆t & 1 & 5.26 & & & \\
\hline Toplam & $\mathbf{1 9}$ & $\mathbf{1 0 0}$ & &
\end{tabular}

Tabloya göre psikolojik danışman adaylarının süpervizyon sürecindeki "rehberlik etme" kategorisine ait metaforlara benzer metaforlar olmakla birlikte farklı metaforlar ile de anlamlandırdıkları görülmektedir. Ayrıca yüz yüze süpervizyon alan psikolojik danışman adaylarının çevrim içi süpervizyon alanlara göre daha fazla metafor oluşturdukları görülmektedir. İlgili metaforlar ve metaforlara yüklenen anlamlardan birkaç örnek şu şekildedir:

"Süreç bana biraz yeni bir dil ögrenmek gibi geldi. En başta bir şey bilmiyorsunuz çok eksiğiniz var belki siz bile ne yaptığınızı anlamıyorsunuz fakat günden güne bir şeyler öğreniyorsunuz ve karşınızdaki insanı daha iyi anlamaya başlıyorsunuz." Yüz yüze süreç

“Süreci 'buğulu bir cama' benzetebilirim. Gerek danışanın gerekse benim gözlerimiz ile gördüklerimiz arasinda bir çeşit buğulu bir cam vardir. Psikolojik danışman adayı olarak danışma sürecindeki bu buğulu camı silmeye ve arkasındaki bilinmeyenleri ortaya çıkarmaya çalıştım. Böylelikle danışanımın kapasitesini, güçlü yanların görmesini sağlayabildim. Danışanın süreç sonrasında söylediği șey, arkadaşlık ilişkilerindeki problemleri çok fazla büyüttügü aslinda ortada bir problem olmadığıydl. Danışan, danışma süreci boyunca ilerlediğimiz bu konudaki bulanıklkkları görebilmeye başladı ve bu bulanıkliğı temizleyerek 
içsel potansiyelini ortaya çıkardı." Yüz yüze süreç

"Kilden bir portre yapmaya çalıştım ama şeklin ortaya tam olarak çıkmaması gibi. Çıkmamasının sebepleri ise kendimi daha çok geliştirmemin gerekmesi, daha ilk deneyimim olduğu için şekli tam olarak ortaya çıkaramadım." Yüz yüze süreç

"Süreci bir tünele benzetiyorum. Sürecin başında çıkışı göremiyordum yalnızca önümde bir yol vardı ve o yolda yürüyordum. Süreç ilerledikçe tünelin sonundaki ışığı görmeye başladım. Artık yolum aydınlıktı nereden gideceğimi önümde hangi engeller olduğunu nasll bir yol izleyeceğimi biliyordum. Sürecin sonunda o aydınlığa ulaştım artık yolumun çok daha aydınlık olduğunu düşünüyorum. Yol hala çok taşlı biliyorum ama artık önümde olan taşları görebiliyorum. Onları nasıl aşabileceğimi biliyorum." Yüz yüze süreç

"Kitap okumak gibiydi çünkü her bir sayfada yeni şeyler ögrendim ve keşfettim. Kitabın sonunda okumam gereken daha fazla kitap varmış gibi hissettim.” Çevrim içi süreç

"Baygınken atılan bir tokat... Birçok doğru bildiğim yanlıştan beni uyandırdı." Çevrim içi süreç

"Süpervizyon süreci benim için iç içe geçmiş kasalar kilidi gibiydi. Iç̧erisindeki değerli nesneye ulaşmak için denediğim farkl anahtarlar sonucunda anahtarlardan hangilerinin işe yarar olduğunu, hangilerinin ise yanlış olduğunu kilitler sayesinde görebiliyordum." Çevrim içi süreç

Katılımcıların "değerlendirme" kategorisine ait geliştirmiş olduklar metaforların frekans ve yüzde dağılımı Tablo 5'te verilmiştir.

Tablo 5. Katılımcıların “Değerlendirme” Kategorisine İlişkin Metaforlarının Frekans ve Yüzde Dağılımı

\begin{tabular}{llllll}
\hline Yüz Yüze Metafor & F & $\mathbf{\%}$ & Çevrim İçi Metafor & F & \% \\
\hline Mevsim değişimi & 1 & 100 & Jüri & 1 & 20 \\
& & & Film & 1 & 20 \\
& & & Maraton koşmak & 3 & 60 \\
\hline Toplam & $\mathbf{1}$ & $\mathbf{1 0 0}$ & & $\mathbf{5}$ & $\mathbf{1 0 0}$ \\
\hline
\end{tabular}

Tablo 5 incelendiğinde “değerlendirme” kategorisinde yüz yüze süpervizyon alan psikolojik danışman adaylarının 1 metafor oluşturdukları, çevrim içi süpervizyon alan psikolojik danışman adaylarının ise 5 farklı metafor oluşturdukları görülmektedir. İki kategoride toplam 6 metafor yer almaktadır. Tabloya göre yüz yüze süpervizyon alan psikolojik danışman adaylarının çevrim içi süpervizyon alanlara göre değerlendirme kategorisinde daha az meta- 
for oluşturdukları görülmektedir. İlgili metaforlar ve metaforlara yüklenen anlamlardan birkaç örnek şu şekildedir:

"Danışma sürecinin başlangıç kısımlarını sonbahara benzettim ben çünkü becerilerim ve bilgim sinırlı sayıdaydı ve yapamıyordum hiçbir şekilde. Sonbahardaki ağaçların yapraklarıydım rüzgarla nereye savrulduğu belli olmayan yapraktım. Olması gereken becerilerim bu aşamada rüzgard yapamadıkça kötü yaptıkça rüzgâr artıyor ve sonbahar yaprağı olan ben artık kuruyup parçalanma evresine geçiyordum fakat amaç oluşturmadan sonra ilkbahar dönemindeki bir yaprak gibi filizlendim, biraz olsun gelişme gösterebildim kendi içimde bunu kimseye yansitamasam da. Ne danışanıma ne danışman hocama." Yüz yüze süreç

"Jüri karşısına çılkmak gibiydi çünkü sürekli sadece değerlendirilip puanlandığımı düşünüyorum.” Çevrim içi süreç

"Benim için süpervizyon bir maraton koşusu gibiydi çünkü almam gereken yol belliydi. Bu yolda süpervizörüm bana antrenörlük yapt..” Çevrim içi süreç

"Benim için süpervizyon süreci film gibiydi. Çünkü süpervizör yönetmendi, ben oyuncuydum." Çevrim içi süreç

\section{Araştırmada Elde Edilen Nicel Bulgular}

Bu başlık altında, aşağıdaki araştırma sorusuna yönelik elde edilen bulgulara yer verilecektir.

1. Yüz yüze ve çevrim içi süpervizyon deneyimine sahip psikolojik danışman adaylarının, süpervizyon süreci değerlendirme envanterine verdikleri puanlar arasında anlamlı bir farklılık var mıdır?

Tablo 6. Süpervizyon Değerlendirme Süreci Envanteri Toplam ve Alt Boyut Puanlarına Yönelik Betimsel İstatistikler

\begin{tabular}{lllll}
\hline Puan Kaynağı & Grup Türü & N & Ortalama & Standart Sapma \\
\hline Amaç Belirleme & Yüz yüze & 17 & 34.25 & 4.02 \\
& Çevrim içi & 35 & 34.74 & 6.45 \\
& Tüm Grup & 52 & 34.58 & 5.74 \\
\hline Geri Bildirim & Yüz yüze & 17 & 46.05 & 5.88 \\
& Çevrim içi & 35 & 50.34 & 5.60 \\
& Tüm Grup & 52 & 48.94 & 6.00 \\
\hline Toplam Puan & Yüz yüze & 17 & 80.29 & 9.26 \\
& Çevrim içi & 35 & 85.08 & 11.17 \\
& Tüm Grup & 52 & 83.52 & 10.73 \\
\hline
\end{tabular}

Belirtilen araştırma sorusuna yönelik bulgular, Lehrman-Waterman ve 
Ladany (2001) tarafindan geliştirilen; Türkçeye uyarlanması Atik (2017) tarafından yapılan Süpervizyonda Değerlendirme Süreci Envanteri (SDSE) kullanılarak elde edilmiştir. Katılımcıların kullanılan ölçme aracına verdikleri yanitlardan elde edilen betimsel istatistikler Tablo 6'da sunulmuştur. Katılımcıların süpervizyon süreci değerlendirme envanterine verdikleri yanıtlardan elde edilen verilerin süpervizyon alınan grup türüne göre karşılaştırılması amacıyla süpervizyon gruplarının, süpervizyonda değerlendirme süreci envanterine verdikleri yanıtlardan elde edilen toplam puanlar incelenmiştir. İlgili sonuçlar Tablo 7'de sunulmuştur.

Tablo 7. Süpervizyonda Değerlendirme Süreci Envanteri Toplam Puanlarının Gruba Göre U-Testi Sonucu

\begin{tabular}{llllll}
\hline Grup & $\mathbf{n}$ & Sıra Ortalaması & Sira Toplamı & $\mathbf{U}$ & $\boldsymbol{p}$ \\
\hline Yüz yüze & 17 & 20.15 & 342.50 & 189.50 & $.035^{*}$ \\
Çevrim içi & 35 & 29.59 & 1035.50 & & \\
\hline${ }^{*} p<.05$ & & & & &
\end{tabular}

Yüz yüze ve çevrim içi süpervizyon sürecine katılan katılımcıların, süpervizyonda değerlendirme süreci envanterinden aldıkları puanların Mann Whitney U Testi sonuçları Tablo 7'de gösterilmiştir. Buna göre, çevrim içi süpervizyon deneyimini yaşayan katılımcılar ile yüz yüze süpervizyon deneyimini yaşayan katılımcıların süpervizyon süreci değerlendirmeleri arasında anlamlı bir fark olduğu bulunmuştur $(\mathrm{U}=189.50, p<.05)$. Sira ortalamaları dikkate alındığında; çevrim içi süpervizyonu deneyimleyen katılımcıların süpervizyon deneyimlerinin, yüz yüze süpervizyonu deneyimleyen katılımcılara göre daha etkili olduğu anlaşılmaktadır. Yüz yüze ve çevrim içi süpervizyon sürecine katılan katılımcıların, Süpervizyonda Değerlendirme Süreci Envanteri "geri bildirim" alt boyutundan aldıkları puanların Mann Whitney U Testi sonuçları Tablo 8'de gösterilmiştir.

Tablo 8. Süpervizyonda Değerlendirme Süreci Envanteri Geri Bildirim Alt Boyutu Toplam Puanlarının Gruba Göre U Testi Sonucu

\begin{tabular}{llllll}
\hline Grup & $\mathbf{n}$ & Sira Ortalaması & Sura Toplamı & $\mathbf{U}$ & $\boldsymbol{p}$ \\
\hline Yüz yüze & 17 & 17.97 & 305.50 & 152.50 & .005 \\
Çevrim içi & 35 & 30.64 & 1072.50 & & \\
\hline$* p<.05$ & & & & &
\end{tabular}

Tablo 8'e göre, çevrim içi süpervizyon deneyimini yaşayan katılımcılar ile yüz yüze süpervizyon deneyimini yaşayan katılımcıların süpervizyon süreci geri bildirim değerlendirmeleri arasında anlamlı bir fark olduğu bulunmuştur $(\mathrm{U}=152.50, p<.05)$. Sıra ortalamaları dikkate alındığında, çevrim içi 
süpervizyonu deneyimleyen katılımcıların, yüz yüze süpervizyonu deneyimleyen katılımcılara göre süpervizyonda geri bildirim deneyimlerinin daha etkili olduğu anlaşılmaktadır. Yüz yüze ve çevrim içi süpervizyon sürecine katılan katılımcıların, Süpervizyonda Değerlendirme Süreci Envanteri "amaç belirleme" alt boyutundan aldıkları puanların Mann Whitney U Testi sonuçları Tablo 9'da gösterilmiştir.

Tablo 9. Süpervizyonda Değerlendirme Süreci Envanteri Amaç Belirleme Alt Boyutu Toplam Puanlarının Gruba Göre U Testi Sonucu

\begin{tabular}{llllll}
\hline Grup & n & Sıra Ortalaması & Sıra Toplamı & U & $\boldsymbol{p}$ \\
\hline Yüz yüze & 17 & 23.71 & 403.00 & 252.00 & .353 \\
Cevrim içi & 35 & 27.86 & 975.00 & & \\
\hline$p<.05$ & & & & &
\end{tabular}

Tablo 9'a göre, çevrim içi süpervizyon deneyimini yaşayan katılımcılar ile yüz yüze süpervizyon deneyimini yaşayan katılımcıların süpervizyon süreci amaç belirleme değerlendirmeleri arasında anlamlı bir farklılık olmadığ 1 bulunmuştur ( $\mathrm{U}=252.50, p>.05)$.

\section{Tartışma}

Araştırma nitel sonuçları incelendiğinde; araştırmaya katılan katılımcılar yüz yüze gerçekleştirilen süpervizyon sürecine ilişkin 34, çevrim içi gerçekleştirilen süpervizyon sürecine ilişkin 34, toplam 68 metafor geliştirmişlerdir. İki kategoride de yolculuk-yol-yolcu metaforlarının (yüz yüze=7, çevrim içi=8) ön plana çıktığı görülmektedir. Psikolojik danışman adaylarının yüz yüze ve çevrim içi süpervizyona ilişkin oluşturdukları metaforların "süpervizör-psikolojik danışman aday ilişkisi”, "süpervizyon sürecinde rehberlik", "içgörü" ve "süpervizyon sürecinde değerlendirme" olmak üzere dört kategori altında toplandığı görülmektedir.

Araştırmaya katılan psikolojik danışman adayları; süpervizör-aday psikolojik danışman ilişkisini güven verici, motive edici ve destekleyici anlamlarındaki metaforlarla nitelendirmiştir. Alanyazında, psikolojik danışman adaylarının süpervizörlerini destekleyici, motive edici, samimi ve objektif dönüt veren kişiler olarak algıladıkları ve olumlu iletişimin süpervizyon sürecine olumlu biçimde yansıdığı; kendileri açısından süreci kolaylaştırdığını belirttikleri görülmüştür (Büyükgöze-Kavas, 2011). Ayrıca etkili bir süpervizyon süreci için süpervizör ve psikolojik danışman adaylarının iş birliği içinde etkili bir ilişki kurmaların önemli olduğu ifade edilmektedir (Bernard ve Goodyear, 2009). Bu bakımdan hem yüz yüze hem de çevrim içi süpervizyon sürecinde 
süpervizör ve aday psikolojik danışmanların etkili bir ilişki kurmasının sürecin verimli olması için oldukça önemli olduğu söylenebilir. Psikolojik danışman adaylarının metaforlarının içerdiği anlamlardan bir diğerinin ise, süpervizyon sürecinde rehberlik olduğu görülmektedir. Süpervizörlerin süreç içinde yönlendirici, bilgi sağlayıcı, destekleyici tutum ve davranışları psikolojik danışman adayları tarafından etkili bulunmaktadır (Aladağ, Kağnıcı, Çankaya, Kocabaş ve Yaka, 2011). Başka bir araştırmada psikolojik danışman adayları; olumlu dönütler sayesinde süpervizyon sürecinden üst düzeyde verim sağladıklarını, kaygılarını kontrol ederek yeni denemelerde bulunduklarını belirtmektedir (Erbaş, Koç ve Esen, 2020). Bu bakımdan süpervizyon sürecinde psikolojik danışman adaylarına olumlu dönütlerle rehberlik etmenin aday psikolojik danışmanların gelişimi açısından önemli olduğu söylenebilir. Metaforlardan elde edilen kategorilerden birisi de içgörüdür. "İçgörü” kategorisi içinde psikolojik danışman adaylarının meslekî ve kişisel anlamda içgörü kazandıklarına dair anlamlar olduğu görülmektedir. Psikolojik danışman adayları süpervizyon sürecinde meslekî özyeterliklerinin arttığını, kaygılar1nın azaldığını ve empati becerilerinin geliştiğini belirtmektedir (Aladağ, 2014). Benzer şekilde süpervizyonun katkıları aday psikolojik danışmanlar tarafından meslekî ve kişisel katkı olmak üzere ele alınmaktadır. İletişim becerilerini ve empatiyi geliştirme kişisel; terapötik becerilerin geliştirme, meslekî deneyim kazanma, etik anlayışı artırma ve meslekî yeterlilik algısının güçlenmesi meslekî katkı olarak ifade edilmektedir (Erbaş, Koç ve Esen, 2020). Psikolojik danışman adaylarının meslekî ve kişisel gelişimlerinden hareketle süpervizyon sürecinin önemli olduğu görülmektedir. Ayrıca özellikle çevrim içi süpervizyon alan aday psikolojik danışmanların süpervizyon sürecinin değerlendirici olduğunu algıladıkları görülmektedir. Deneyimsiz psikolojik danışman adaylarının hissettikleri performans kaygısı ile birlikte sunacakları yardım ilişsisinin sınırlarını çizmede, danışanların ifadelerine odaklanarak ilişkilendirmede ve sorun kavramsallaştırmada yaşadığı zorluklar (Erkan-Atik, Arıcı ve Ergene, 2014) bağlamında değerlendirildiklerini düşünmelerine yol açabilir. Bu bakımdan aday psikolojik danışmanların değerlendirmeye yükledikleri anlamın anlaşılması önem arz etmektedir.

Araştırmanın nicel bulgularına bakıldığında; çevrim içi süpervizyonu deneyimleyen katılımcıların süpervizyon deneyimlerinin, yüz yüze süpervizyonu deneyimleyen katılımcılara göre anlamlı düzeyde daha etkili olduğu anlaşılmaktadır. Benzer şekilde çevrim içi süpervizyonu deneyimleyen katılım- 
c1ların, yüz yüze süpervizyonu deneyimleyen katılımcılara göre süpervizyonda geri bildirim deneyimlerinin daha etkili olduğu anlaşılmaktadır. Ayrıca çevrim içi süpervizyon deneyimini yaşayan katılımcılar ile yüz yüze süpervizyon deneyimini yaşayan katılımcıların süpervizyon süreci amaç belirleme değerlendirmeleri arasında anlamlı bir farklılık olmadığı bulunmuştur. Alanyazında çevrim içi ve uzaktan süpervizyon sürecinin ele alındığı araştırmaların yurt dışı alanyazında olduğu bilinmektedir (Bacigalupe, 2010; Bengtsen ve Jensen, 2015; Butler ve Constantine, 2006; Chapman, Baker, Nassar, McMillan ve Gerler, 2011; Coker, Jones, Staples ve Harbach, 2002; Coker ve Schooley, 2009; Jakob, Weck ve Bohus, 2013; Nelson, Nichter ve Henriksen, 2010; Snow ve Coker, 2020; Sorlie, Gammon, Bergvik ve Sexton, 1999; Stebnicki ve Glover, 2001; Woo, Bang, Lee ve Berghuis, 2020). Alanyazında çevrim içi süpervizyonun etkililiği ve çevrim içi süpervizyon sürecinde teknolojik imkânların sağlanmasına yönelik araştırmalara da rastlanılmaktadır (Coker, Jones, Staples ve Harbach, 2002; Layne ve Hohenshill, 2005; Vaccaro ve Lambie, 2007).

Alanyazında, çevrim içi süpervizyon sürecinin etkililiğine yönelik bazı araştırma bulgularına rastlanılmaktadır (Perry, 2012; Vaccaro ve Lambie, 2007). Bununla birlikte süpervizyon sürecinde teknolojik imkânların yararları olduğu kadar bazı güçlüklerinin de olduğu ifade edilmektedir (Altekruse ve Brew, 2000; Watson, 2003). Bağlantı problemi, teknolojik imkânlara erişim ve teknolojik araçların kullanımına özgü özel nitelikler gibi olası güçlükler, bunlararasında sayılabilir. Buna rağmen çevrim içi öğrenmenin, yüz yüze gerçekleşen bir ortamda gerçekleşecek öğrenme hedeflerine ulaşma ile benzer sonuçlar verebileceği de ifade edilmektedir (Bowen, Chingos, Lack ve Nygren, 2012). Bu anlamda, çalışmada yer alan çevrim içi süpervizyon sürecini deneyimleyen katılımcıların yüz yüze süpervizyon sürecini deneyimleyen katılımc1lara göre süpervizyon sürecini daha etkili değerlendirmeleri dikkat çekici bir bulgu olarak ön plana çıkmaktadır. Öte yandan, çevrim içi süpervizyon sürecinde hem psikolojik danışman adaylarına hem de danışanlara yönelik denetimin tam olarak gerçekleşemeyeceğine dair endişelerin var olduğu bilinmektedir (Armstrong ve Schneiders, 2003; Glosoff, Renfro-Michel ve Nagarajan, 2016; Nelson, Nichter ve Henriksen, 2010). Buna rağmen katılımcılar tarafindan çevrim içi süpervizyon sürecinin hem toplam puan düzeyinde hem de geri bildirim alt boyutunda anlamlı düzeyde daha etkili bulunmasının da dikkate değer bir bulgu olduğu söylenebilir. Son olarak süpervizör ve psikolojik danışman adaylarının iki farklı yerde bulunduklarında, her iki tarafın 
da yüz yüze gerçekleştirilecek süpervizyon sürecine katılım göstermeleri için önemli miktarda zaman harcaması gerekmektedir (Wood, Miller ve Hargrove, 2005). Zaman yönetimi konusundaki avantajlarından dolayı çevrim içi süpervizyonun etkililiğine dair elde edilen sonucun da bu anlamda değerlendirilebileceği düşünülmektedir.

Alanyazında çevrim içi süpervizyon süreci ile yüz yüze süpervizyon süreci arasında etkililik konusunda anlamlı bir farklılık olmadığına dair araştırma bulguları da yer almaktadır (Barak ve Hen, 2008; Bender ve Dykeman, 2016; Coker, Jones, Staples ve Harbach, 2002; Conn, Powell ve Roberts, 2009; Cook ve Doyle, 2002; Nelson, Nichter ve Henriksen, 2010). Çevrim içi süpervizyon sürecinde süpervizörlerin yetkinliğinin ve teknolojik araçları kullanma konusundaki yeteneklerinin, çevrim içi süpervizyon sürecinin verimliliğini etkilediği ifade edilmektedir (Baltrinic, O'Hara ve Jencius, 2016; Chapman, Baker, Nassar-Mcmillan ve Gerler, 2011; McMahon ve Simons, 2004). $\mathrm{Bu}$ anlamda süpervizörlerin yetkinliğinin ve teknolojik araçları kullanma konusundaki yeteneklerinin, ilgili araştırma bulgularından farklı olarak çevrim içi sürecin verimliliğini arttırdığı ifade edilebilir. Ayrıca alanyazında çevrim içi ve yüz yüze süpervizyon sürecinin etkililiğini karşılaştıran çalışmaların pandemi süreci gibi özel koşullar altında gerçekleştirilmediği göz önünde bulundurulduğunda, araştırma sonuçlarının farklılaşmamasının olası bir durum olarak belirdiği düşünülmektedir.

\section{Sonuç}

$\mathrm{Bu}$ çalışmada, bireyle psikolojik danışma uygulaması dersi kapsamındaki süpervizyon sürecinin hem nitel hem nicel yöntemler kullanılarak araşt1rılmasının alanyazına katkı sağladığı söylenebilir. Alanyazında çevrim içi ve yüz yüze süpervizyon süreçlerinin karşılaştırılmasına yönelik karma desenli herhangi bir araştırmaya rastlanılmaması, bu çalışmanın katkılarından biri olarak ifade edilebilir. Psikolojik danışman adaylarının süpervizyon sürecine dair oluşturdukları metaforlarda süpervizör-aday danışman ilişkisine önem verdikleri, süpervizörlerinin rehberlik ettiğini ve kendilerini değerlendirdiğini düşündükleri ve içgörü kazandıkları görülmektedir. Bu sonuçlar, süpervizyon sürecinde aday danışmanların süpervizör ve süreç açısından beklentilerine 1 şı tutmaktadır. Bununla birlikte araştırmanın birtakım sınırlılıkları bulunmaktadır. Araştırmanın nicel kısmında çevrim içi ve yüz yüze süpervizyon sürecine gönüllü şekilde katılan psikolojik danışman adaylarının sayısı farklılık göstermektedir. Bu bakımdan gruplar arasında sayısal olarak farklılık oluşmuştur. Ayrıca psikolojik danışman adaylarının süpervizyon yaşantıları, süpervizyon 
süreci değerlendirme envanteri ve metafor çalışma formunun ölçtüğü özelliklerle sınırlıdır. Psikolojik danışman adaylarının süpervizyon sürecini verimli şekilde ilerletmeleri için programlar geliştirilip deneysel açıdan sınanabilir. Süpervizyon sürecinin psikolojik danışman adaylarının profesyonel gelişimleri için kritik önemi göz önünde bulundurulduğunda, bu sürecin mümkün olan en yüksek standartlara kavuşturulması gerekmektedir (Harvey ve Struzziero, 2008). Bu anlamda çevrim içi, yüz yüze ve hibrit süpervizyon süreçlerinin karşılaştırılacağ farklı araştırmaların da gerçekleştirilmesinin önemli ve değerli olduğu düşünülmektedir. Ayrıca teknolojik imkânların özel bir teknik olarak görülmesinden ziyade, süpervizör ve psikolojik danışman adayları arasındaki iletişimi desteklemekte kritik bir rol üstlendiği ifade edilmektedir (Rousmaniere, 2014). Bu anlamda teknolojik imkânlarla desteklenen süpervizyon süreçlerinin etkililiğine yönelik araştırmaların da gerçekleştirilmesi önerilebilir. Son olarak, çevrim içi süpervizyon sürecinde süpervizörlerin yetkinliklerinin ve teknolojik araçları kullanma yeteneklerinin önemli bir alan olduğu göz önünde bulundurulduğunda, bu konuda çalışmaların arttırılmasının gerekli olduğu düşünülebilir.

\section{Kaynakça}

Aladağ, M. (2014). Psikolojik danışman eğitiminin farklı düzeylerinde bireyle psikolojik danışma uygulaması supervizyonunda kritik olaylar. Ege Eğitim Dergisi, $15,428-475$.

Aladağ, M. ve Bektaş, D. Y. (2009). Examining individual-counseling practicum in a Turkish undergraduate counseling program. Eurasian Journal of Educational Research (EJER), 37, 53-70.

Aladağ, M., Kağnıcı, D. Y., Çankaya, Z. C., Kocabaş, E. Ö. ve Yaka, B. (2011). Psikolojik danışman eğitiminde grupla çalışma yeterliğinin kazandırılması: Ege Üniversitesi örneği. Ege Ĕgitim Dergisi, 12(2), 21-43.

Altekruse, M. K. ve Brew, L. (2000). Using the web for distance learning. J. W. Bloom ve G. R. Walz, (Ed.), Cybercounseling and cyberlearning: Strategies and resources for the millennium içinde (129-141). Alexandria: American Counseling Association.

Altun, T. ve Camadan, F. (2013). Rehber öğretmenlerin rehber öğretmen (psikolojik danışman) kavramına ilişkin algılarının metafor analizi yoluyla incelenmesi. Kastamonu Ĕ̈itim Dergisi, 21(3), 883-918.

Amanvermez, Y., Zeren, S. G., Erus, S. M. ve Buyruk-Genç, A. (2020). Supervision and peer supervision in online setting: Experiences of psychological counselors. Eurasian Journal of Educational Research, 86, 249-268.

Armstrong, P. ve Schneiders, I. (2003). Video and telephone technology in supervision and supervision training. Technology in counselling and psychotherapy: A practitioner's guide. Basingstoke, UK: Palgrave.

Atik, G., Çelik, E. G., Güç, E. ve Tutal, N. (2016). Psikolojik danışman adaylarının 
yapılandırılmış akran grup süpervizyonu sürecindeki metafor kullanımına ilişkin görüşleri. Ege Eğitim Dergisi, 17(2), 597-619.

Atik, Z. (2017). Psikolojik danışman adaylarının bireyle psikolojik danışma uygulaması ve süpervizyonuna ilişkin değerlendirmeleri. Yayımlanmamış doktora tezi, Hacettepe Üniversitesi Eğitim Bilimleri Enstitüsü.

Babacan, E. (2014). Anadolu güzel sanatlar lisesi öğrencilerinin müzik kavramına ilişkin algıları: metafor analizi. Eğitim ve Öğretim Araştırmaları Dergisi, 3(1), 124-132.

Bacigalupe, G. (2010). Supervision 2.0: E-supervision a decade later. Family Therapy Magazine, 9(1), 38-41.

Baltrinic, E. R., O’Hara, C. ve Jencius, M. (2016). Technology-assisted supervision and cultural competencies. T. Rousmaniere ve E. Renfro-Michel, (Ed.), Using technology to enhance clinical supervision içinde (47-66). Alexandria: American Counseling Association.

Barak, A. ve Hen, L. (2008). Exposure in cyberspace as means of enhancing psychological assessment. A. Barak, (Ed.), Psychological aspects of cyberspace: theory, research, applications içinde (129-162). Cambridge, UK: Cambridge University Press.

Bender, S. ve Dykeman, C. (2016). Supervisees' perceptions of effective supervision: A comparison of fully synchronous cybersupervision to traditional methods. Journal of Technology in Human Services, 34(4), 326-337.

Bengtsen, S. S. ve Jensen, G. S. (2015). Online supervision at the university-A comparative study of supervision on student assignments face-to-face and online. Tidsskriftet Laering og Medier (LOM), 8(13), 1-23.

Bernard, J. M. ve Goodyear, R. K. (2009). Fundamentals of clinical supervision. Needham Heights, MA: Allyn \& Bacon.

Bowen, W. G., Chingos, M. M., Lack, K. A. ve Nygren, T. I. (2012). Interactive learning online at public universities: Evidence from random trials. New York, $\mathrm{NY}$ : Ithaca $\mathrm{S}+\mathrm{R}$.

Bradley, L. J. ve Ladany, N. (2001). Counselor supervision: Principles, process, and practice (3. bask1). Philadelphia, PA: Brunner-Routledge.

Butler, S. K. ve Constantine, M. G. (2006). Web-based peer supervision, collective self-esteem, and case conceptualization ability in school counselor trainees. Professional School Counseling, 10(2), 146-152.

Büyükgöze-Kavas, A. (2011). Bireysel ve grupla psikolojik danışma uygulamalarına yönelik bir değerlendirme. Türk Ĕ̆itim Bilimleri Dergisi, 9(2), 411-432.

Carmichael, K. D. (2000). Using a metaphor in working with disaster survivors. Journal of Specialists in Group Work, 25(1), 7-15.

Chapman, R. A., Baker, S. B., Nassar-McMillan, S. C. ve Gerler Jr, E. R. (2011). Cybersupervision: Further examination of synchronous and asynchronous modalities in counseling practicum supervision. Counselor Education and Supervision, 50(5), 298-313.

Coker, J. K., Jones, W. P., Staples, P. A. ve Harbach, R. L. (2002). Cybersupervision in the first practicum: Implications for research and practice. Guidance \& $\mathrm{Co}$ unseling, 18(1), 33-37.

Coker, J. K. ve Schooley, A. (2009). Investigating the effectiveness of clinical super- 
vision in a CACREP accredited online counseling program. 2009 ACES Conference'da sunulan bildiri, San Diego, $C A$.

Conn, S. R., Powell, B. R. ve Roberts, R. L. (2009). Attitudes and satisfaction with a hybrid model of counseling supervision. Educational Technology \& Society, 12, 298-306.

Cook, J. E. ve Doyle, C. (2002). Working alliance in online therapy as compared to face-to-face therapy: Preliminary results. Cyberpsychology \& Behavior, 5, 95105.

Council for Accreditation of Counseling and Related Educational Programs (CACREP). (2016). 2016 CACREP standards. Alexandria, VA: Author.

Creswell, J. W. ve Plano-Clark, V. L. (2011). Designing and conducting mixed method research. Thousand Oaks, CA: Sage.

Erbaş, M. M., Koç, İ. ve Esen, E. (2020). Psikolojik danışman adaylarının süpervizyon sürecine ilişkin görüşlerinin incelenmesi: Manisa Celal Bayar Üniversitesi örneği. Mehmet Akif Ersoy Üniversitesi Eğitim Fakültesi Dergisi, 1(53), 183205.

Erkan-Atik, Z., Arıcı, F. ve Ergene, T. (2014). Süpervizyon modelleri ve modellere ilişkin değerlendirmeler. Türk Psikolojik Danışma ve Rehberlik Dergisi, 5(42), 305-317.

Erkan-Atik, Z. ve Yıldırım, İ. (2017). Süpervizyonda Değerlendirme Süreci Envanteri Türkçe Formu'nun geçerlik ve güvenirlik çalışması. Ege Eğitim Dergisi, 18(1), 146-173.

Eryılmaz, A. ve Mutlu, T. (2018). Gelişimsel kapsamlı süpervizyon modeline ilişkin psikolojik danışman adaylarının görüşlerinin incelenmesi. Elektronik Sosyal Bilimler Dergisi, 17(65), 123-141.

Glosoff, H. L., Renfro-Michel, E. ve Nagarajan, S. (2016). Ethical issues related to the use of technology in clinical supervision. T. Rousmaniere ve E. RenfroMichel, (Ed.), ACA using technology to enhance clinical supervision içinde (31-46). Alexandria, VA: American Counseling Association.

Harvey, V. S. ve Struzziero, J. A. (2008). Professional development and supervision of school psychologists (2. bask1). Thousand Oaks, CA: Corwin Press.

Holloway, E. L. (1995). Clinical supervision: A systems approach. Thousand Oaks, CA: Sage.

İlhan, T., Sarıkaya, Y. ve Yöntem, M. K. (2018). Süpervizör Rolleri Ölçeği'nin (SRÖ) geliştirilmesi. Abant İzzet Baysal Üniversitesi Eğitim Fakültesi Dergisi, 18(4), 2103-2122.

Jakob, M., Weck, F. ve Bohus, M. (2013). Live supervision: From the one-way mirror to video-based online supervision. Verhaltenstherapie, 23, 170-180.

Kalkan, B. ve Can, N. (2019). Psikolojik danışman eğitiminde süpervizyon: Türkiye'deki mevcut durumun ve standartların araştırılması. Adiyaman Üniversitesi Ĕ̈itim Bilimleri Dergisi, 9(2), 271-290.

Kanz, J. E. (2001). Clinical-supervision.com: Issues in the provision of online supervision. Professional Psychology: Research and Practice, 32(4), 415-420.

Karataş, K. ve Sönmez, N. (2019). Lise öğrencilerinin rehberlik hizmetlerine ve rehber öğretmene ilişkin görüşleri: metaforik bir analiz. Journal of Theoretical Educational Science, 12(3), 915-934.

Kaya, Y. S. (2017). Öğretmen adaylarının matematiksel örnekleri algılayışları üzerine 
bir metafor analizi. Bartın Üniversitesi Ë̆itim Fakültesi Dergisi, 6(1), 48-67.

Layne, C. M. ve Hohenshil, T. H. (2005). High tech counseling: Revisited. Journal of Counseling \& Development, 83, 222-226.

Lehrman-Waterman, D. ve Ladany, N. (2001). Development and validation of the evaluation process within supervision inventory. Journal of Counseling Psychology, 48(2), 168-177.

Levitt, H., Korman, Y. ve Angus, L. (2000). A metaphor analysis in treatments of depression: Metaphor as a marker of change. Counseling Psychology Quarterly, 13, 151-165.

McKinley, M. T. (2019). Supervising the sojourner: Multicultural supervision of international students. Training and Education in Professional Psychology, 13(3), 174-179.

McMahon, M. ve Simons, R. (2004). Supervision training for professional counselors: An exploratory study. Counselor Education and Supervision, 43(4), 301-309.

Meydan, B. (2015). Bireyle psikolojik danışma uygulamasında mikro beceri süpervizyon modeli'nin etkililiğinin incelenmesi. Türk Psikolojik Danışma ve Rehberlik Dergisi, 5(43), 55-68.

Meydan, B. (2019). Facilitative and hindering factors regarding the supervisory relationship based on supervisors' and undergraduate supervisees' opinions. $\mathrm{Pe}$ gem Ĕ̈itim ve Öğretim Dergisi, 9(1), 171-208.

Meydan, B. ve Koçyiğit-Özyiğit, M. (2016). Süpervizyon ilişkisi: psikolojik danışma süpervizyonunda kritik bir öğe. Ege Eğitim Dergisi, 17(1), 225-257. London: SAGE.

Nelson, J. A., Nichter, M. ve Henriksen, R. (2010). On-line supervision and face-toface supervision in the counseling internship: An exploratory study of similarities and differences.

http://counselingoutfitters.com/vistas/vistas10/Article_46.pdf

Özabacı, N. ve Başak, B. E. (2013). Öğretmenlerin öğrenme yetersizliği olan öğrencileri ile ilgili algılarının metafor analizi yoluyla incelenmesi. Hacettepe Üniversitesi Eğitim Fakültesi Dergisi, 28(1), 269-280.

Özpolat, A. R. (2014). Psikolojik danışma ve rehberlik bölümü öğrencilerinin "psikolojik danışma” kavramına ilişkin sahip oldukları metaforlar. Kastamonu Eğitim Dergisi, 22(1), 385-396.

Özyürek, R. (2009). Okullarda psikolojik danışma ve rehberlik uygulamaları ve öğrencilere sağlanan süpervizyon olanakları: Ulusal bir tarama çalışması. Türk Psikolojik Danışma ve Rehberlik Dergisi, 4(32), 54-63.

Patton, M. Q. (2002). Qualitative research \& evaluation methods (3. bask1). Thousand Oaks, California: Sage Publications.

Pekdoğan, S. ve Kanak, M. (2015). Okul öncesi öğretmen adaylarının yaratıcılığa ilişkin algıları: Metafor analizi örneği. Uluslararası Ĕ̆itim Bilimleri Dergisi, 3, 138-147.

Perry, C. W. (2012). Constructing professional identity in an online graduate clinical training program: Possibilities for online supervision. Journal of Systemic Therapies, 31, 53-67.

Rousmaniere, T. (2014). Using technology to enhance clinical supervision and training. C. E. Watkins ve D. Milne, (Ed.), International handbook of clinical supervision içinde (204-237). New York, NY: Wiley Publishers. 
Sidekli, S., Pekdemir, E. ve Yorulmaz, A. (2021). İlkokul dördüncü sınıf öğrencilerinin "üçgen, kare ve dikdörtgen” kavramlarına ilişkin metaforları. Anadolu Journal of Educational Sciences International, 11(1), 116-134.

Siviş-Çetinkaya, R. ve Karaırmak, Ö. (2012). Psikolojik danışman eğitiminde süpervizyon. Türk Psikolojik Danışma ve Rehberlik Dergisi, 4(37), 107-121.

Snow, W. H. ve Coker, J. K. (2020). Distance counselor education: past, present, future. Professional Counselor, 10(1), 40-56.

Sorlie, T., Gammon, D., Bergvik, S. ve Sexton, H. (1999). Psychotherapy supervision face-to-face and by video conferencing: A comparative study. British Journal of Psychotherapy, 15(4), 452-462.

Stebnicki, M. A. ve Glover, N. M. (2001). E-supervision as a complementary approach to traditional face-to-face clinical supervision in rehabilitation counseling: Problems and solutions. Rehabilitation Education-New York-Pergamon Press, 15(3), 283-294.

Tabachnick, B. G. ve Fidell, L. S. (2007). Experimental designs using ANOVA. Belmont: Thomson/Brooks/Cole.

Uygun, T., Gökkurt, B. ve Neslihan, U. (2016). Üniversite öğrencilerinin matematik problemine ilişkin algılarının metafor yoluyla analiz edilmesi. Bartın Üniversitesi Ĕgitim Fakültesi Dergisi, 5(2), 536-556.

Vaccaro, N. ve Lambie, G. W. (2007). Computer-based counselor-in-training supervision: Ethical and practical impliations for counselor educators and supervisors. Counselor Education \& Supervision, 47, 46-57.

Vannucci, M. J., Whiteside, D. M., Saigal, S., Nichols, L. ve Hileman, S. (2017). Predicting supervision outcomes: what is different about psychological assessment supervision? Australian Psychologist, 52(2), 114-120.

Watson, J. C. (2003). Implementing computer technology into the delivery of counseling supervision. Journal of Technology in Supervision, 3. http://jtc.colstate.edu/vol3_1/Watson/Watson.htm

Woo, H., Bang, N. M., Lee, J. ve Berghuis, K. (2020). A meta-analysis of the counseling literature on technology-assisted distance supervision. International Journal for the Advancement of Counselling, 42(4), 424-438.

Wood, J. V., Miller, T. W. ve Hargrove, D. S. (2005). Clinical supervision in rural settings: A telehealth model. Professional Psychology: Research and Practice, 36(2), 173-179.

Yıldırım, A. ve Şimşek, H. (2013). Sosyal bilimlerde nitel araştırma yöntemleri. Ankara: Seçkin Yayıncılık.

Yıldız, A. D. ve Türk, E. G. (2018). Okul psikolojik danışmanlarının görev sınırları ve sorumluluklarının metaforlar ile analizi. Kastamonu Eğitim Dergisi, 26(4), 1207-1216. 